\title{
透析患者に対する腹部手術の検討
}

\author{
大平整爾 阿部憲司佐々木偉夫 今 忠 正* 佐藤 和 広* \\ 岩見沢市立総合病院外科・透析センター 北海道大学第 1 外科*
}

(昭和 60 年 8 月 28 日受付)

key words : 急性上部消化管出血, 緊急手術, 心肺機能の低下, 術前後の透析, 虚血性腸管壊死

〈要旨〉

過去 5 年間に私どもが経験した腹部手術 48 例を検討の対象とした。 内訳は胃切除 17 例（胃・十二指腸潰瘍 11 例, 胃癌 6 例), 虫垂切除 9 例 (すべて化膿性または壊死性で内 4 例は穿孔), イレウス 7 例 (腸切除 5 例, 瘑着剝離 2 例), 胆囊摘出 2 例, 脾摘出 2 例, 子宮摘出 2 例（癌 1 例, 出血性筋腫 1 例), 直腸切断・人工肛門造設（直腸癌） 1 例, 虚 血性腸管壊死に対する腸管切除 5 例, その他 3 例であった。

これらの経験からまず開腹術前・中・後に共通する問題点をとりあげ，もっとも症例の多かった胃切除例を中心に 考察した.

胃切除後の追跡調査結果を腎機能正常な胃切除症例と対比すると真の体重増加, 賓血の改善, 活動力の回復など総 じて透析患者では有意に劣っており特別な栄養学上の工夫, 管理が必要であった。 心機能の高度低下例では SCUF, $\mathrm{CAVH}$ 等の血液浄化法上の変法も有効であった。次いで, 虚血性腸管壊死 5 例に 6 回の手術を行ったが, 病変は回盲 部, 上行結腸に限局性にみられ病変部腸管は著しく賓血状で菲薄化していた。しかし，比較的大きな腸間膜動脈より 中枢側には血栓形成を認めていない，開腹所見ではすべての汎発性腹膜炎の状態でありながら臨床的には必ずしも激 裂な症状を呈してはおらず手術の決定には困難を伴った。

いずれの症例も持続的低血圧か关れに近い状態にあることや, 透析間体重増加が大きく従って 1 回透析あたりの除 水量が至適量をはるかに越えているなど, 透析患者の病態に特徵的な因子の関与が強く示唆されたためこれらについ ても考察を加えた.

\section{Clinical analysis of abdominal surgery in patients on chronic hemodialysis}

Seiji Ohira, M. D., Kenji Abe, M. D., Hideo Sasaki, M. D., Tadamasa Kon, M. D.*, Kazuhiro Sato, M. D.* Departments of Surgery and Dialysis Therapy, Iwamizawa Municipal General Hospital ; Department of Surgery, Hokkaido University, School of Medicine*

A review of the experience with 48 patients on chronic hemodialysis who underwent abdominal surgical procedures is presented.

Abdominal procedures included 17 gastrectomies for bleeding gastric or duodenal ulcers (11 cases) and gastric cancer ( 6 cases) ; 9 appendectomies ; 5 intestinal resections and 2 freeings of intestinal adhesion for ileus ; 2 cholecystectomies; 2 splenectomies for splenomegaly; 2 hysterectomies for 1 uterine cancer and 1 bleeding myoma uteri ; 1 combined abdomino perineal resection for rectal cancer ; 5 intestinal resections for ischemic necrosis of the intestine and 3 others.

There was one operative death. Perioperative management of the patients, especially those who underwent gastrectomies is discussed.

Postoperative follow-up studies of gastrectomized patients with chronic renal failure were compared with those of the patients with normal renal function and it became clear that the former was definitely inferior in postoperative increase in body weight, improvement of anemia, physical activities and so on.

大平 整爾 岩見沢市立総合病院外科・透析センター

厂 068 岩見沢市 9 条西 7 丁目（01262-2-1650） 
Therefore the postoperative hemodialysis patients require special consideration in their nourishment.

The most common complication after the surgery was congestive heart failure probably due to decreased cardiopulmonary function and overhydration based on diminished lean body mass or increased catabolism. This means that one of the most important factors after the surgery is how to determine the most appropriate body weight.

Modified blood purification methods such as SCUF (slow continuous ultrafiltration) and CAVH (continuous arteriovenous hemofiltration) caused essentially no symptoms in patients with highly disturbed cardiopulmonary function.

Ischemic necrosis of the intestines was observed in 5 cases and 6 resections of the necrotized intestines were carried out. Most of the patients did not always show serious abdominal manifestations which made the diagnosis difficult. All five patients were considered to have non occlusive ischemic disease because obstruction of a major intestinal vessel could not be documented in any case. All patients were hypotensive and the ultrafiltration volume was far beyond an appropriate limit in most hemodialyses, which further aggravated the hypotension.

It is contended that persistent hypotension, arterial disease and intestinal motility disturbances occurring in terminal uremic patients could be responsible for this complication.

\section{緒言}

慢性透析患者の増加と延命に伴って各種の手術を行う 機会が多くなってきている.

透析技術の進歩と患者の一般状態の向上などによって 確実に手術成績は向上しているが, 手術侵襲による心肺 機能の低下および尿毒症状態の悪化, 出血傾向, 易感染 性, 輸液量の制限, 創傷治癒の遅延などのため慢性透析 患者は手術に対して poor risk case と言わざるを得な い.

術前・中・後の管理を慎重に行わなければならない所 以であり，本論文では私どものこれまでの手術例のうち 腹部手術をとりあげ各種の臨床的検討を行って今後の参 考に供したい.

\section{対象・方法}

昭和 $55 \sim 59$ 年の 5 年間に当科で施行した腹部手術 48 例（表 1) を対象として手術前中後の状態を臨床的に分 析した.

なお, 手術症例の半数は他透析施設からの依頼であっ た.

\section{結果}

\section{術前透析}

定期手術の場合, 月・火曜日と連日血液透析を行い水 曜日に手術を行うことを原則とした，術前各種検査の目 標値は太田ら ${ }^{1)}$ 準じ心胸比 $50 \%$ 以下, 血清 $\mathrm{K}$ 值 3.0 $\sim 4.0 \mathrm{mEq} / l, \mathrm{BUN}$ 濃度 $50 \mathrm{mg} / \mathrm{d} l$ 以下, 血清クレアチ ニン濃度 $10 \mathrm{mg} / \mathrm{d} l$ 以下, Hct 值 $25 \sim 30 \%$, 血清蛋白濃 度 $6.5 \mathrm{~g} / \mathrm{d} l$ 以上とし体重は, それまでの dry weight よ り $1,2 \mathrm{~kg}$ 減少させることにした。これらの条件を満足し えない場合には随時, 追加透析を行い必要な輸血, 輸液 を施行した。
輸血はできる限り新鮮血か保存血を使用し, 赤血球濃 厚液の場合には新鮮凍結血漿を併用した。定期の胃切除 症例はすべて術前より高カロリー輸液とした。

消化管出血や腹膜炎などのため緊急手術を要した症例 は 26 例であるが，手術日が定期透析日にあたるものが 14 例であった. 残る 12 例のうち 5 例に $6.0 \mathrm{mEq} / l$ 以上 の高カリウム血症か溢水状態を認めたため術直前に追加

\begin{tabular}{|c|c|c|c|}
\hline 術 式 & \multicolumn{2}{|l|}{ 名 } & 小 計 \\
\hline 胃切除 & $\begin{array}{l}\text { 胃・十二指腸潰瘍 } \\
\text { 胃 癌 }\end{array}$ & $\begin{array}{c}11 \text { 例 } \\
6\end{array}$ & 17 例 \\
\hline 虫垂切除 & $\begin{array}{l}\text { 化膿性または壊死性 } \\
\text { 穿孔性 }\end{array}$ & $\begin{array}{l}5 \\
4\end{array}$ & 9 \\
\hline イレウス & $\begin{array}{l}\text { 絞扼性（腸切除） } \\
\text { 腸管㾙着（瘺着剝離） }\end{array}$ & $\begin{array}{l}5 \\
2\end{array}$ & 7 \\
\hline 胆囊摘出 & $\begin{array}{l}\text { 壊疸性胆囊炎 } \\
\text { 慢性胆囊炎 } \\
\quad \text { (いずれも「ビ」結石 }\end{array}$ & $\begin{array}{l}1 \\
1\end{array}$ & 2 \\
\hline 脾摘出 & 貧血, 脾腫 & 2 & 2 \\
\hline 子宮摘出 & $\begin{array}{l}\text { 子宮癌 } \\
\text { 出血性子宮筋腫 }\end{array}$ & $\begin{array}{l}1 \\
1\end{array}$ & 2 \\
\hline $\begin{array}{l}\text { 直腸切断, } \\
\text { 人工肛門 }\end{array}$ & 直腸癌 & 1 & 1 \\
\hline 腸管切除 & 虚血性腸管壊死 & 5 & 5 \\
\hline その他 & $\begin{array}{l}\text { 人工肛門閉塞 } \\
\text { 内胆汁瘻 } \\
\text { 卵巣囊腫破裂 }\end{array}$ & $\begin{array}{l}1 \\
1 \\
1\end{array}$ & 3 \\
\hline & & 合 計 & 48 例 \\
\hline
\end{tabular}

表 1 透析患者に対する腹部手術症例 
（緊急）透析を施行した.

\section{2. 麻酔}

初期の急性虫垂炎 4 例に腰椎麻酔を行った。このうち 3 例が腰麻後の低血圧に通常使用する昇圧剤に対する反 応が十分でなく，胸内苦悶感，嘔気を訴えた。このため その後は術前エホチール，エフェドリンに反応して血圧 の上昇する症例のみ下腹部手術であれば，腰椎麻酔とし ている.今回の集計 48 例のうち腰麻は合計 8 例であり残 る 40 例は全身麻酔である。

全麻は前投薬に Atarax P $50 \mathrm{mg}$, Atropin $0.5 \mathrm{mg}$ を 用い主として気管内捙管下の GOF 麻酔とした。筋弛緩 には挿管時のみ SCC 25〜 50 mg を使用し以降は pancuronium chloride (Mioblock ${ }^{\circledR}$ ) 2〜4 mg/回を静注し， nerve stimulator を適宜用いて筋弛緩度をチェックし た。

全麻 40 例中 1 例に遷延性無呼吸がみられた. 以下，こ の症例の経過を略述する。

\section{症例: 52 歳, 男性.}

現病歴：外来患者として月・木曜日の週 2 回，夜間透 析を継続し全身状態は良好であった。

昭和 55 年 4 月 11 日通常のごとく血液透析を受けたが

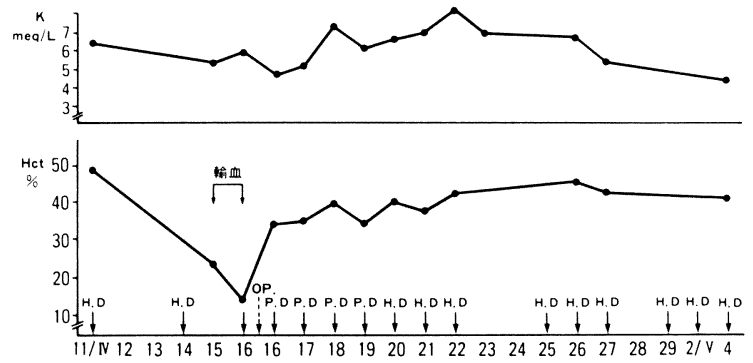

図 1 男性, 52 歳

\begin{tabular}{lc}
\hline BUN & $138.0 \mathrm{mg} / \mathrm{d} l$ \\
血清クレアチニン & 15.5 \\
血清 $\mathrm{Na}$ & $134.8 \mathrm{mEq} / l$ \\
$\mathrm{~K}$ & 4.7 \\
$\mathrm{Ca}$ & 4.5 \\
$\mathrm{Cl}$ & 110.0 \\
血清蛋白 & $6.2 \mathrm{~g} / \mathrm{d} l$ \\
$\mathrm{~A} / \mathrm{G}$ 比 & 1.2 \\
赤血球 & $204 \times 10^{4}$ \\
$\mathrm{Hb}$ & $8.6 \mathrm{~g} / \mathrm{d} l$ \\
$\mathrm{Hct}$ & $22.7 \%$ \\
白血球 & 9,000 \\
低血圧, 頻脈, 胸苦 & \\
\hline
\end{tabular}

表 2 手術直前の血液生化学値など (症例： 52 歳, 男性)
翌 12 日に上腹部不快感を覚えたという。1 13 日には夕ー ル便を 3 回排泄しているが，患者から何ら訴えや報告が なかったため, 14 日通常の方式で血液透析を開始したと ころ透析中に大量のタール便の排泄があり, 4 時間 42 分 で血液透析を中止した。前回の透析直前に $48 \%$ あった Hct 值はこの時点で $28 \%$ に低下しており, 消化管大量出 血は確実であった，入院の上，保存的療法を開始しつつ 経過を観察したがタール便は続き, しかも鮮紅色の色調 が強くなって輸血（保存血 $1,600 \mathrm{~m} l$, 新鮮血 $1,400 \mathrm{~m} l$ ) を 合計 $3,000 \mathrm{~m} l$ 行ったが Hct 值は最低 $13 \%$ に低下した

(図 1，2）。このため手術を決意し術直前に regional heparinizationのもとで血液透析を行った(表 2 ). なお, 一般状態不良のため消化器管造影, 内視鏡検査は施行し えなかった。

手術と術後経過：麻酔は気管内插管 GOF で気管内挿 管時に SCC $50 \mathrm{mg}$, その後, 適宜ミオブロックを使用し た.その総量は $12 \mathrm{mg}$ であった。

上腹部正中切開にて開腹すると胃内に凝血を触れ小 腸, 大腸の全長にわたって黒色の内容物が見られた。出 血性胃潰瘍は胃小彎側で胃角のやや口側に位置し $5 \times 7$ mmの大きさで, kissing ulcerであった. 潰瘍底にはと

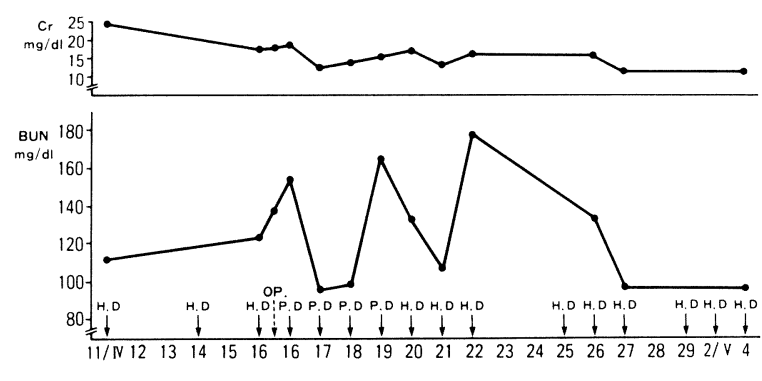

図 2 男性, 52 歳

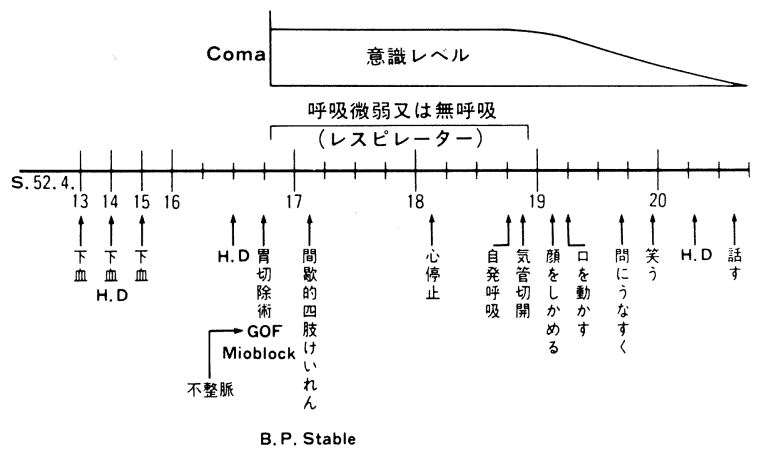

図 3 術後の経過 （症例 52 歳, 男性） 


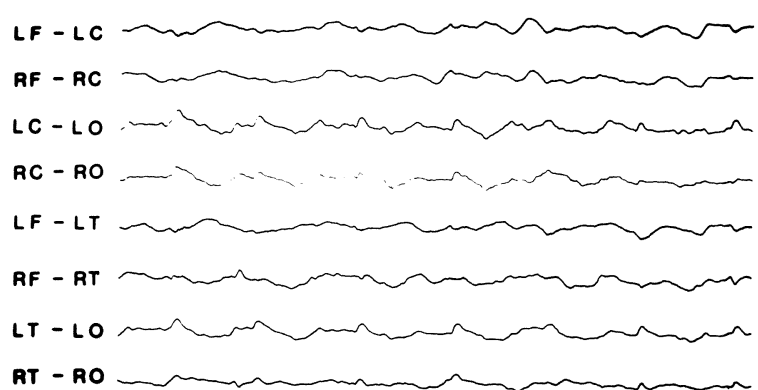

図 4 脳波（昭和 52 年 4 月 18 日，昏睡時). 症例 52 歳, 男性

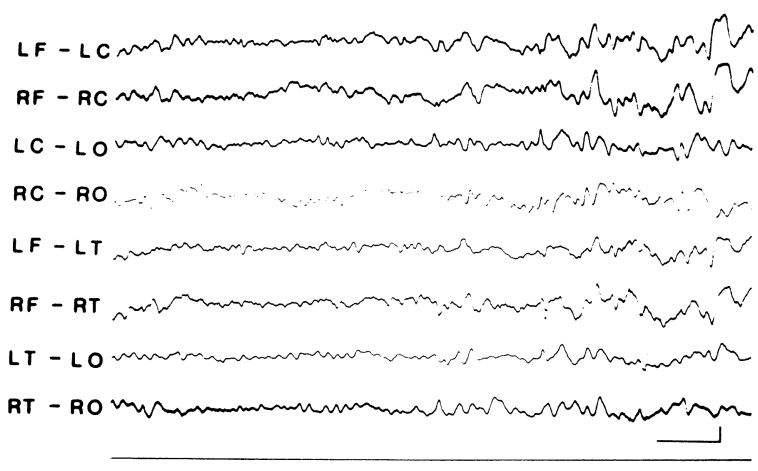

図 5 脳波（昭和 52 年 4 月 21 日）血液透析中. 症例 52 歳, 男性

開眼中. 時々大きな呼吸をする. $\theta$ 波, $\delta$ 波を主と し， $\alpha$ 波をほとんど見ない

もに小動脈の露出を肉眼的に認めた（病理組織学的には 潰瘍は 2 個とも U1 III で良性であった).

4/5 胃覀全摘を行いBillroth II 法（結腸後）で胃空腸 吻合を行った。術後, 自発呼吸および意識の回復が著し く遷延した（図 3 ).

いったん抜管し mask で補助呼吸を行ったが, 換気不 全のため 5 分後に気管内再插管した。この間低酸素状態 にあったものと考えられる。

昏睡状態が約 48 時間継続し脳波では $\alpha$ 波成分がまっ たく見られず全波が平坦記録であった（図 4 ）。この間， 腹膜灌流を頻回に行ったが BUN は最高 $180 \mathrm{mg} / \mathrm{d} l$, 血 清 $\mathrm{K}$ 值は最高 $7.5 \mathrm{mEq} / l$ に達した（図 $1 ， 2$ )。一方，血 清クレアチニン濃度は $10 \sim 15 \mathrm{mg} / \mathrm{d} l$ を変動し under -dialysis とは考えがたく，BUN，血清 $\mathrm{K}$ 值の高值は catabolism 几進のためと考えられた. 術後, Hct 值は安 定して $35 \%$ 以上を維持していた.

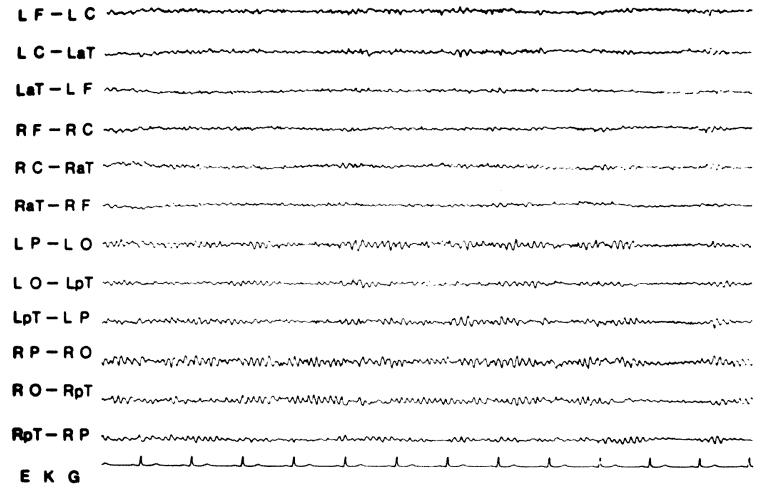

図 6 脳波 (昭和 52 年 5 月 26 日, 術後 10 日目) 症例 52 歳, 男性

8.5 9.0 C/S の $\alpha$ 波がよく出現するようになり， ほぼ正常化した脳波である。意識，良識なども通 常に復している

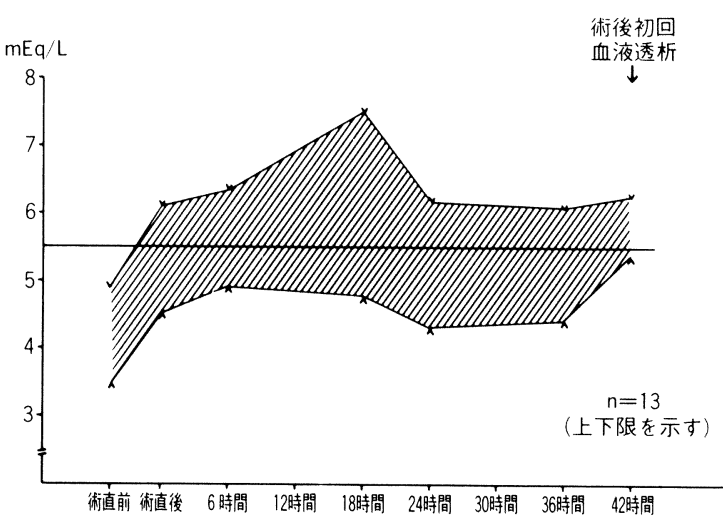

図 7 胃切除術後より初回血液透析までの血清カリウム の変動

約 2 日間の昏睡の後, 意識レベルはしだいに回復し術 後 4 日目に自発的に話しうるようになり知能障害は残さ なかった. 脳波も正常化している（図 5,6 ). その後, 週 3 回の定期血液透析へもどり全身状態は急速に回復し た.この症例の手術時, 当院には nerve stimulator がな く, 自発呼吸の回復を十分確認せずに抜管したため, hypoxia をきたし脳に影響を与えたものと考えられる。 遷延性無呼吸または低呼吸状態が存在する場合には, レスピレーターに接続すべきことを学んだ1).

\section{3. 手術死亡}

開腹手術 48 例中 1 例を術後 7 時間目に失った.この症 例は後述する虚血性腸管壊死による汎発性腹膜炎で, 術 前すでにショック状態にあった。

4. 術中管理と手術手技

気管内插管後, 血清 $\mathrm{K}$ 值を $30 \sim 60$ 分間隔で測定し, 5 . $5 \mathrm{mEq} / l$ 以上の場合 $50 \%$ glucose $200 \mathrm{~m} l+$ regular insu- 
lin $20 \mathrm{u}$ を点滴しつつ推移をみることにしている。なお， 念のため血液ガス分析も術前・中・後, 適宜行っている. 緊急胃切除術 13 例の血清 $\mathrm{K}$ 值の変動をみるとかなりの 幅が認められ, 術前透析が不十分であったり, 術前・中 に輸血を行ったか, 術中 GI 療法を行わなかった症例が 当然ながら高カリウム血症となった（図７）.

手術手技は愛護的処置と丹念な止血操作を行うことに つきる。

\section{5 . 術後の血液透析}

再開の時期は血清 $\mathrm{K}$ 值, BUN, 血圧上昇, 血液ガス所 見, 呼吸状態, 胸部X線像などを参考に決定したが，第 2 病日以降（術後 36〜 48 時間）に行うことが多かった. 抗凝固剂は術後出血をできる限り避けるため術後 $1 \sim 2$

\begin{tabular}{|c|c|c|}
\hline 1) & $\begin{array}{l}\text { 急性脳症候群 } \\
\text { (acute brain syndrome) }\end{array}$ & 5 例 \\
\hline 2) & 自発呼吸回復遅延 & 1 例 (2 日間)* \\
\hline 3) & 賞醒遅延 ～～～～～ & 1 例 ( 2 日間) ${ }^{*}$ \\
\hline 4) & 後出血 & 2 例 \\
\hline 5) & 縫合不全 & なし \\
\hline 6) & 術創感染 ～～～～～染 & 3 例 \\
\hline 7) & 排気遅延（ 3 日以上） & 10 例 \\
\hline 8) & 内シャント血栓形成 & 3 例 \\
\hline 9) & 呼吸器感染 & 7 例** \\
\hline 10) & 肺うっ血, 心肥大 & 15 例*** \\
\hline 11) & 脳梗塞 & 1 例 \\
\hline 12) & 肝機能障害 & 8 例 \\
\hline
\end{tabular}

\section{*同一症例}

$$
\text { **は***に重複 }
$$

表 3 透析患者開腹手術の術後早期にみられた 合併症 (48 例, 49 回手術)
回の血液透析は FOY 単独から FOY十へパリンを使用 したが2), 保険診療上, FOY のこのような使用が認めら れていない問題がある.

術後 18 時間目に血清 $\mathrm{K}$ 值 $7.2 \mathrm{mEq} / l$ と高值をとった 出血性胃潰瘍の術後症例も GI 療法, カルチコール静注, 陽イオン交換樹脂の注腸によって血清 $\mathrm{K}$ 值は低下しこの ため緊急透析を必要としなかった。

直腸癌のため直腸切断術および人工肛門造設術を行っ た 68 歳男性の症例では, 術後図 8 のようにうつ血性心不 全を合併し, 臨床的にも呼吸困難, 喀痰喀出の増加およ びチアノーゼが出現し脈圧が低下した，通常の血液透析 では症状が多く除水困難であったため, 旭メディカル社 製 PAN-50P (血液容積 $50 \mathrm{~m} l$ ) を用いた slow continuous ultrafiltration $(\mathrm{SCUF})^{3)}$ と continuous arteriovenous hemofiltration $(\mathrm{CAVH})^{4)}$ を行い心胸比, 肺 うっ血の著明な改善を得て臨床像も安定した.

術後透析を行う上で最も問題になったのは目標体重の 設定の仕方であった．消化管手術例では経口摂取が再開 されるまで静脈栄養を必要とする。しかし，これによっ ても, catabolism の䒕進は抑制しがたく lean body mass は消耗し, dry weightは低下するため体重増加が なくとも溢水状態に傾きがちである. 経口攝取量が安定 するまで頻回に dry weight を検討する必要がある.

6. 術後合併症

術後早期（2 週間以内）にみられた合併症を表 3 に列 記した. 最も頻度の高かった合併症は肺うっ血, 心肥大 であった(図 8 ). 15 例のうち臨床的に呼吸困難, 喀痰増 量などを伴ったものは 6 例であった.いずれも除水の強 化で主訴ならびに胸部X線像の所見は改善している。ま

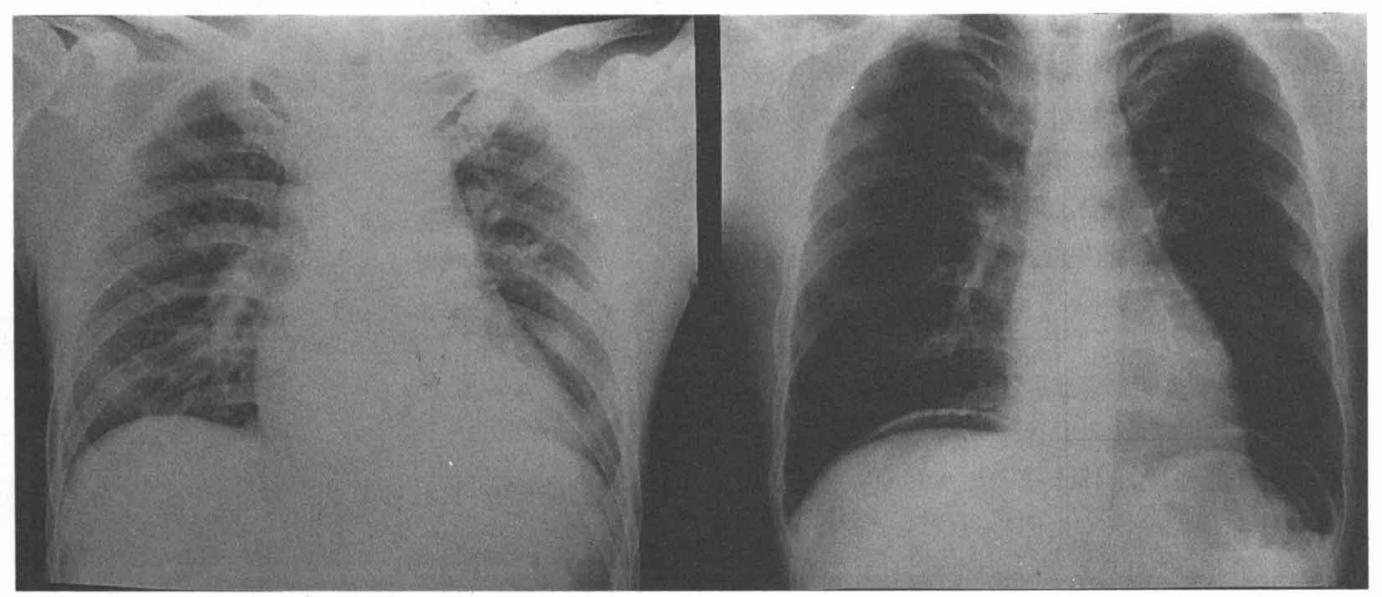

図 8 胸部X線写真

腹会陰式直腸切断術後に発生したうっ血性心不全(左)．除水の強化で心胸比，肺野とも正常化した(右) 
た, この 15 例中 7 例に発熱, 白血球増多症および咳嗽が あり, 喀疾から Klebsiella pneumoniae, Streptococcus pneumoniae, Hemophilus influenzae, Klebsiella aeruginosa などが検出された。感受性を示した抗生剤によ く反応した.

肝機能障害は GOT, GPT が 150 u以上になった症例 である。これら 8 例はいずれも消化管大量出血のため約 2,000 m/の新鮮血または保存血の輸血を受けている。全 例 $4 \sim 6$ 週間で GOT, GPT は正常化している. なお, 発黄例はなかった。

排気までに術後 3 日以上要した例が 10 例に及んで透 析患者の開復術後の排気は腎機能正常者に比較してやや 遅延する傾向にあるとの印象を得た。ただ，これらはす べて術後の高カリウム血症かその予防に陽イオン交換樹 脂を注腸投与した症例である。

急性脳症候群 (acute brain syndrome) $)^{5)}$ とは, 術後 数日間に発生する時間, 場所に対する見当識の障害, 異 常な言動で時に mania, coma にまで発展するものであ る. 今回の集計 48 例中 5 例にみられた. 本症候群には多 くの要因が関与していると考えられ，1) hypoxia，2) 代謝異常，3）薬剤，4）睡眠障害，5）重症感染症， 6) ストレス，7）脳内 SOL などが比較的多い原因で ある.

私どもの経験した 5 例では 7 ）を除いて他の 6 因子が 幾つかずつ関与していたと推定された. 手術が終了した 抜管直後には hypoxia が生じやすく, $\mathrm{PaO}_{2}$ が 70 $\mathrm{mmHg}$ 以下であれば酸素マスクなテントで酸素を供給 すべきである. BUN の上昇や血清電解質の異常は腸管 出血症例にはしばしば見られ経静脈高カロリー輸液に伴 う高血糖も看過しえない. 薬剤では抗生剤の過剩投与が 疑われた症例があった。

いずれにせよ, 急性脳症候群は私どもを困惑せしめる ものであるが, 患者を十分に鎮静せしめることが先決で あり是正可能な中毒性, 代謝性の因子がからんでいるこ とも多く, この意味では術後早期透析が望ましい.

後出血 2 例とは胃腸吻合か腸管吻合を行った 28 例中 の術後に認められた消化管出血である. 出血点は 1 例で は胃腸吻合部にみられたが他の 1 例は明確にしえなかっ た.

2 例とも私どもの初期の経験例であり術後第 1 回の血 液透析をプロタミンを用いた局所へパリン化法で行って 数時間後に発生, 低血圧と Hct 值の減少によって気づい ている，幸い，保存的療法で止血し再手術を要しなかっ た.

7. 胃切除例の術前後の経過

胃十二指腸潰瘍 11 例および胃癌 6 例の計 17 例に胃切
除術を行った.このうち 13 例が大量の吐下血のため緊急 手術となっている.私どもは出血性消化性潰崵において, 非内視鏡的止血法 (シメチジン, セクレチンの点滴静注, トロンビン・アルロイド Gの経胃管的注入など）および 内視鏡所見を緊急に得たうえで各種の内視鏡的止血法6) を試みつつ， 1 ） $1,000 \mathrm{~m} l$ の急速輸血によってもショッ ク状態の改善や血圧の回復・安定が得られない場合や, 2 ) いったん, 止血後 $48 \sim 72$ 時間以内に大量出血が反復 して起こる場合を緊急手術の適応としてきた ${ }^{7,8}$. 緊急手 術例は胃癌 2 例, 胃潰瘍 8 例, 十二指腸潰瘍 3 例で通常 $30.2 \pm 7.7 \%$ (平均 $\pm \mathrm{SD}$ ) の Hct 值を維持していたもの が, 輸血開始時 $16.3 \pm 3.4 \%$ と著減していた。手術は $1,739 \pm 675 \mathrm{~m} /$ 保存血または新鮮血の輸血後, Hct 值が $26.0 \pm 1.9 \%$ に回復した時点で行われている. 術直前の追 加透析は高力リウム血症または湓水を呈した 5 例に必要 であった。手術例の多くはU1 III, IVか kissing ulcer で 潰瘍底に血管の露出を認めるものであった(図 9 ). 良性 潰瘍では $2 / 3 \sim 4 / 5$ の広範囲胃切除を行った.

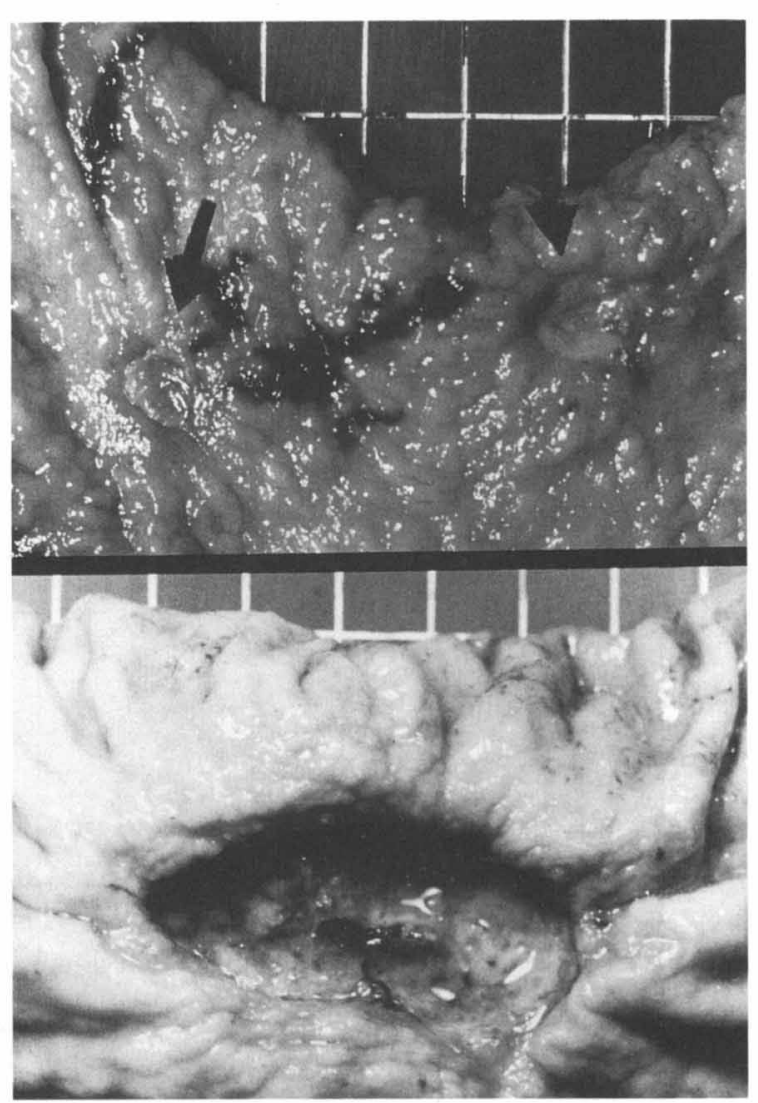

図 9 摘出標本

上：胃角部の kissing ulcer

下：深い潰瘍でその底部に小脈管の露出が認められる 
なお，過去 5 年間に手術例と同様，短時間に同程度の Hct 值の低下が認められながら, 前述の保存的療法で一 時的にせよ止血した症例が 6 例あった点を特記したい.

胃癌は 6 例であるが， 2 例は上述のように持続的出血 のため緊急手術がなされた。

待機手術 4 例は上腹部不快感, 食思不振, 体重減少, 便潜血反応持続陽性などのため消化管造影, 上部消化管 内視鏡検查を受け，生検の結果によって最終的に胃癌と 診断されたものである.リンパ腺廓清は今回の症例では R2 であった. 組織学的進行度は Stage I 2 例, Stage II 2 例, Stage III 2 例であり癌死は現在までない.

透析患者に対する抗癌剤の使用についてはいまだ不明 の点が多い. Cyclophosphamide (Endoxan $\left.{ }^{\circledR}\right)$ は血漿で の蛋白結合率が $20 \%$ 以下であり, 大部分は肝で代謝され る. 分子量は 261 であるため血液透析によって除去され る.このため腎機能正常者の血中半減期が 6 時間である のに対して, 血液透析中は 2.5 時間と短縮する ${ }^{9)} .5$ -fluorouracil（分子量 130）の代謝も腎障害によって影 響されず血液透析によって約 $40 \%$ が除去され過剩投与

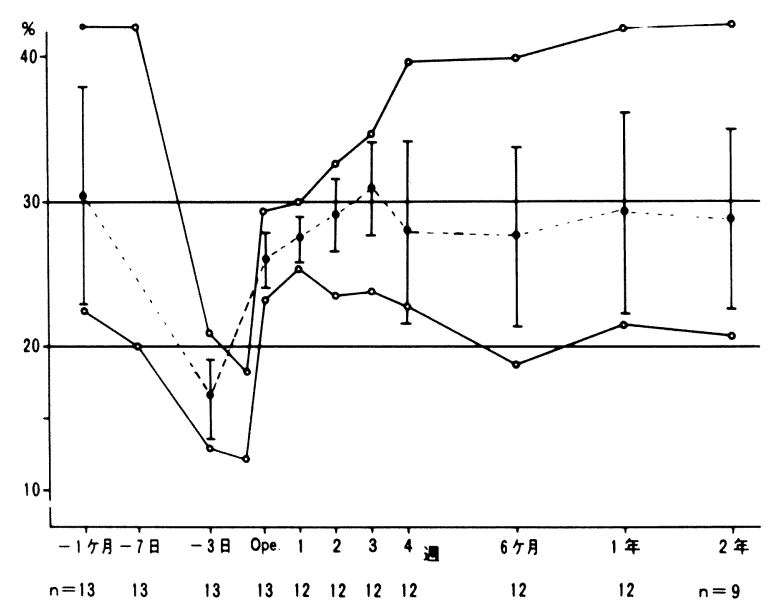

図 10 胃切除術前後の Hct 值の変動
のおそれはない辛.これらが使用しやすいが，造血器系統 の副作用には十分留意する必要がある。私どもは Stage II，IIIの 4 例に Endoxan (50〜100 mg/日) か 5FU (100 〜 $200 \mathrm{mg} /$ 日)を内服させたが，2 例は白血球減少のため 間歇的投与となっている。この点は腎機能正常の胃癌症 例の場合と同様である.

胃切除術後の Hct 值の変動を良性潰瘍 9 例について みると図 10 (丸印はこのグループの最高, 最低值を示す) のようにおおむね 4 週間後には術前 1 力月前の值に回復 するが，個人差が大きい，術後の低 Hct（貧血）症例は 術前もやはり Het 值は低值であり, 術後の摄取カロリー も不足していた。

次に胃切除術後の体重変化を腎機能正常群と透析患者 群とで比較した．前者はすべて良性潰瑒であり後者には 良性潰瘍 11 例に早期胃癌 1 例を加えた。両群の年齢には 有意な差はなかった。透析患者群の体重はその時点での dry weight であるが，腎機能正常群に比較して減少率が 大きくその回復も有意に（P<0.01）遅延している（図 11).

腎機能正常群の 12 例中 8 例が穿孔，4 例が出血であり その 6 例に術後 1 週間の中心静脈栄養 $\quad(1,600 \sim 2,000$

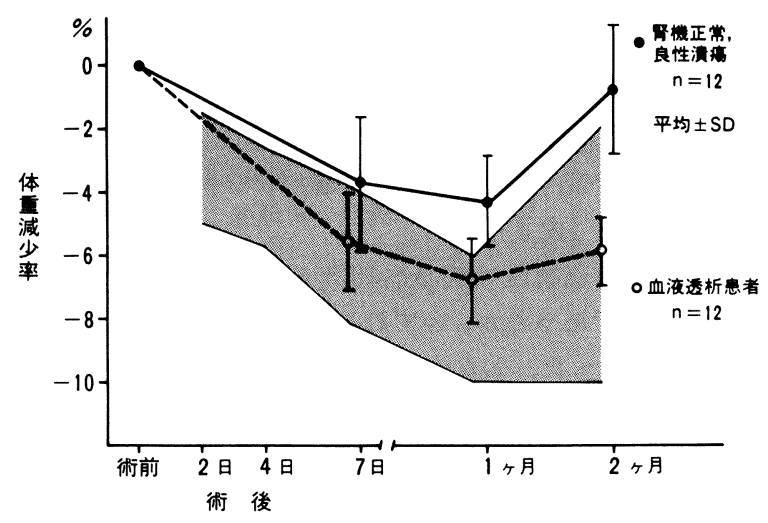

図 11 胃切除術後の体重変化

\begin{tabular}{|c|c|c|c|c|c|c|c|c|c|c|c|c|}
\hline & \multirow{2}{*}{ 症例 } & \multirow{2}{*}{ 性 } & \multirow{2}{*}{ 年齢 } & \multirow{2}{*}{$\begin{array}{l}\text { 発症時 } \\
\text { 透析歴 }\end{array}$} & \multirow{2}{*}{ 除水率 } & \multirow{2}{*}{ 血 圧 } & \multicolumn{2}{|c|}{ 透 析 中 } & \multirow{2}{*}{$\operatorname{Hct}(\%)$} & \multirow{2}{*}{$\begin{array}{l}\text { 血小板 } \\
\left(\times 10^{4}\right)\end{array}$} & \multirow{2}{*}{ 病 変 腸 管 } & \multirow{2}{*}{ 転帰 } \\
\hline & & & & & & & 低血圧 & 腹 痛 & & & & \\
\hline \multirow{2}{*}{1} & & \multirow{2}{*}{ 男 } & 65 歳 & 2 年 & $4-10 \%$ & $110-80$ & m & m & $30-40$ & 21.8 & 回腸下部 & \multirow{2}{*}{ 生 } \\
\hline & & & 66 歳 & 3 年 & $4-6 \%$ & $110-80$ & $H$ & H & $30-40$ & 24.2 & 上行 $\cdot$ 横行結腸 & \\
\hline 2 & & 男 & 64 歳 & 4 力月 & $4-5 \%$ & $130-80$ & H & m & $25-30$ & 26.7 & 回盲部 $\cdot$ 上行結腸 & 生 \\
\hline 3 & & 男 & 36 歳 & 5 年 6 力月 & $6-10 \%$ & $110-60$ & m & H & $30-38$ & 20.6 & 回盲部 & 死 \\
\hline 4 & & 女 & 56 歳 & 7 年 & $5-7 \%$ & $80-40$ & m & + & $25-30$ & 19.8 & 回盲部 & 生 \\
\hline 5 & & 男 & 59 歳 & 9 年10力月 & $6-8 \%$ & $98-50$ & m & H & $25-30$ & 26.7 & 回盲部 & 生 \\
\hline
\end{tabular}

表 4 虚血性腸管壊死の手術症例 


\begin{tabular}{|c|c|c|c|c|c|c|}
\hline & \multicolumn{2}{|c|}{ 症 例 1} & 症例 2 & 症例 3 & 症症例 4 & 症例 5 \\
\hline & \multicolumn{2}{|r|}{65 歳 } & \multirow[b]{2}{*}{64 歳 } & \multirow[b]{2}{*}{36 歳 } & \multirow[b]{2}{*}{56 歳 } & \multirow[b]{2}{*}{59 歳 } \\
\hline & (1) & (2) & & & & \\
\hline 赤血球 $\left(\times 10^{4}\right)$ & 355 & 402 & 235 & 344 & 328 & 299 \\
\hline $\mathrm{Hb}(\mathrm{g} / \mathrm{d} l)$ & 10.8 & 12.0 & 9.0 & 10.0 & 10.9 & 10.1 \\
\hline Hct $(\%)$ & 32.4 & 37.5 & 26.0 & 34.4 & 36.7 & 29.2 \\
\hline 白 血 球 & 14,400 & 22,300 & 8,200 & 4,400 & 10,900 & 9,800 \\
\hline 血小板 $\left(\times 10^{4}\right)$ & 21.8 & 33.7 & 26.7 & 14.6 & 26.4 & 29.9 \\
\hline 血清蛋白 $(\mathrm{g} / \mathrm{d} l)$ & 6.4 & 7.0 & 6.9 & 6.1 & 6.8 & 6.2 \\
\hline$A / G$ 比 & 1.2 & 1.3 & 1.3 & 0.9 & 1.1 & 1.0 \\
\hline GOT/GPT & $10 / 42$ & $30 / 38$ & $14 / 18$ & $56 / 86$ & $18 / 22$ & $42 / 48$ \\
\hline $\mathrm{BUN}(\mathrm{mg} / \mathrm{d} l)$ & 111.2 & 81.0 & 87.2 & 47.1 & 61.0 & 79.2 \\
\hline 血清 $\mathrm{Cr}$ & 15.1 & 17.7 & 14.2 & 6.7 & 10.9 & 13.7 \\
\hline 血清 $\mathrm{Na}(\mathrm{mEq} / l)$ & 138 & 131 & 132 & 140 & 141 & 142 \\
\hline 血清 K & 6.2 & 5.1 & 6.5 & 3.8 & 4.9 & 4.8 \\
\hline $\begin{array}{r}\text { 血清アミラーゼ } \\
(\mathrm{IU} / l)\end{array}$ & 994 & 1,540 & 1,086 & 2,480 & 1,080 & 776 \\
\hline 血圧 $(\mathrm{mmHg})$ & $100 / 66$ & $90 / 40$ & $130 / 74$ & $50 / ?$ & $124 / 80$ & $118 / 72$ \\
\hline
\end{tabular}

表 5 虚血性腸管壊死症例の術前検査成績

$\mathrm{kcal} /$ 日）を行ったのに対して，透析患者 12 例では全例 術後 10 日間 $1,800 \sim 2,200 \mathrm{kcal} /$ 日の中心静脈栄養を行っ ている ${ }^{1,10,11)}$. 経口摂取の開始は透析患者群で術後平均

\section{9 日（3〜7日）であった。}

腎機能正常群の 10 例が 4 力月後には術前体重を上 回ったのに対して透析群では 6 例にとどまった.

8. 虚血性腸管壊死をきたした症例の分析 ${ }^{12)}$

腹部手術 48 例中虚血性腸管壊死が 5 例あり 6 回の手 術を行った（表 4 ）。

発症時の透析歴は約 $2 \sim 10$ 年にわたっており年齢も 36〜66 歳であったが，いずれも持続性低血圧かそれに近 い状態であった。しかも透析間体重増加率が各々の症例 の dry weight の $4 \sim 10 \%$ にも及び， 1 回透析あたりの 除水量が至適量をはるかに越えることが多かった症例で あった。

このため, 透析終了時はさらに低下することが多かっ た。これらの症例は従来から透析中または終了時に腹部 アンギーナの症状を呈することが多く, 補液, 昇圧強心

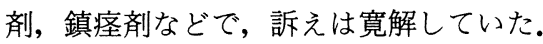

心電図, 胸部 X線像には著変は認めていない, 発症時 の主訴は下腹部痛, 腹部膨満, 食思不振, 嘔気, 嘔吐ま たは下痢と強い倦急感であった。明らかな下血を呈した 症例はなかった。下腹部に圧痛は認めたが腹膜炎に随伴 する筋性限御は著明ではなかった。

腹部単純 $\mathrm{X}-\mathrm{P}$ 上，いずれの症例も腸管内ガス像の増 加を認めたが典型的なニーボー形成ではなくまた腹腔内
に free air は証明できなかった，注腸造影，大腸ファイ バースコープの適応と考えたが，低血圧状態で倦急感が 強く施行しえなかった，術前の検査成績はその主なもの を表 5 に示した.白血球が 10,000 以下の症例が 3 例あっ た。臨床的には虫垂炎, イレウス, 大腸䅡室炎, 大腸癌 などを疑診しつつ手術にふみ切った，開腹すると膿汁か 悪臭ある浸出液が多量に認められ各々の症例で表 4 に記 載した部位の腸管に壊死を認めた。全例に浸出液の培善 で E. coli を検出している，病変腸管と正常腸管との境 界は通常の腸間膜血栓症の場合に見るほど明瞭ではな く, いずれの症例も上・下腸間膜動脈, 回結腸動脈に微 弱ながら拍動を認め血栓は触知しなかった。病変部位に 肉眼的穿孔はなかったがいずれの例も腸管壁が著しく菲 薄していた（図 12）.

術後 7 時間目に死亡した症例 ( 36 歳, 男性) は術 直前ショック状態にあったが, 回盲部壊死のほか, 胆囊 底部にも壊死性変化を認めた。

手術は全例壊死腸管の切除と腸管吻合, 腹腔内ドレ ナージを施行した。

病理組織学的所見（図 13～16）：腸管全層に変性壊死 が認められこれに高度の炎症性反応が随伴しているのが 特徵的であった。病変の主体は虚血による大腸および終 末回腸粘膜の凝固壊死で二次的に漿膜側へ炎症が波及し たものと考えられる．炎症性細胞の強い浸潤は腸管全層 に見られ一部に菌塊が存在することもあった。

術後，上述のように 1 例が死亡したほかは残る 4 例は 

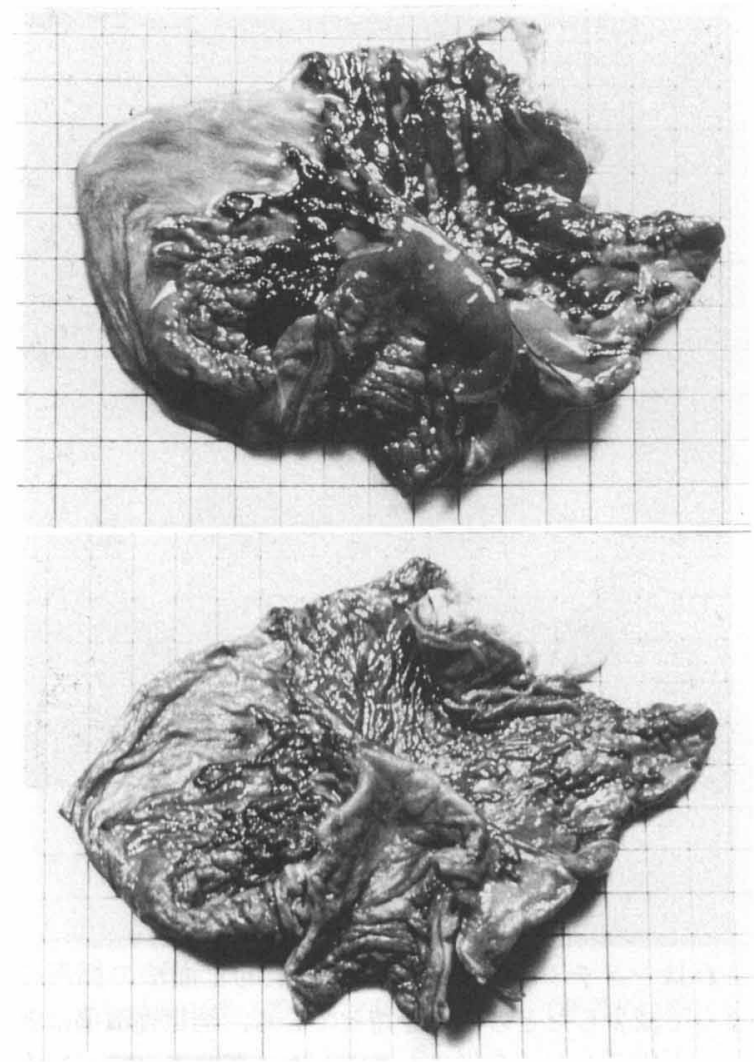

図 12 摘出標本 ( $36 \mathrm{y}, \mathrm{M})$

回盲部腸管の壊死例(上は摘出物, 下はそのホルマリン 固定後)

肉眼的にも粘膜の壊死脱落が著しく腸管壁の菲薄化が 高度である

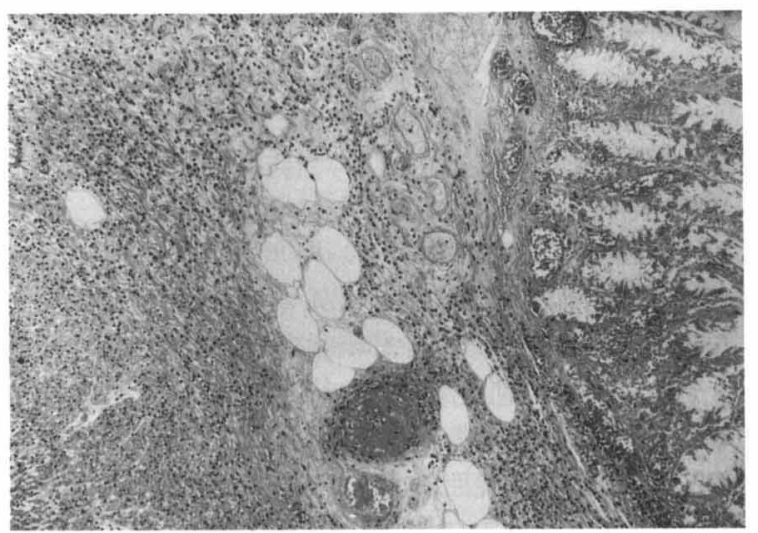

図 13 組織像. 症例

65 歳, 男性 (第 1 回手術).

粘膜は剝離潰瘍となり粘膜下層から筋層に高度の炎症 反応を認めた。壁内血管に血栓または静脈炎を認めな かった

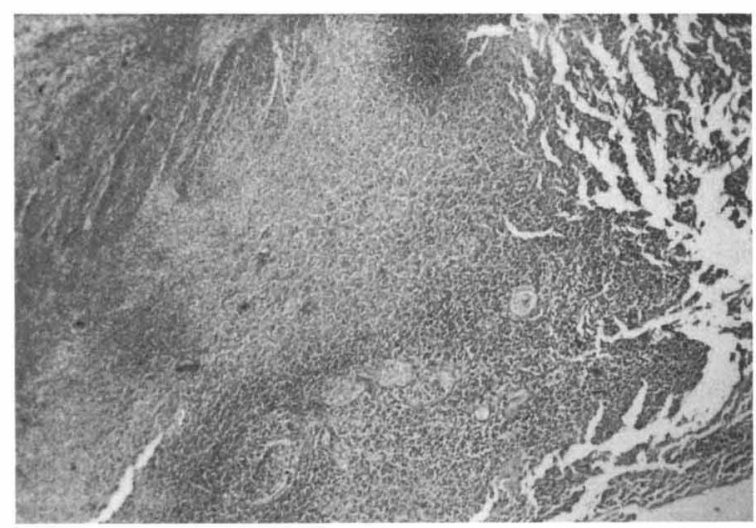

図 14 組織像. 症例 66 歳, 男性 (第 2 回手術時) 広範囲の腸管壊死像がみられる

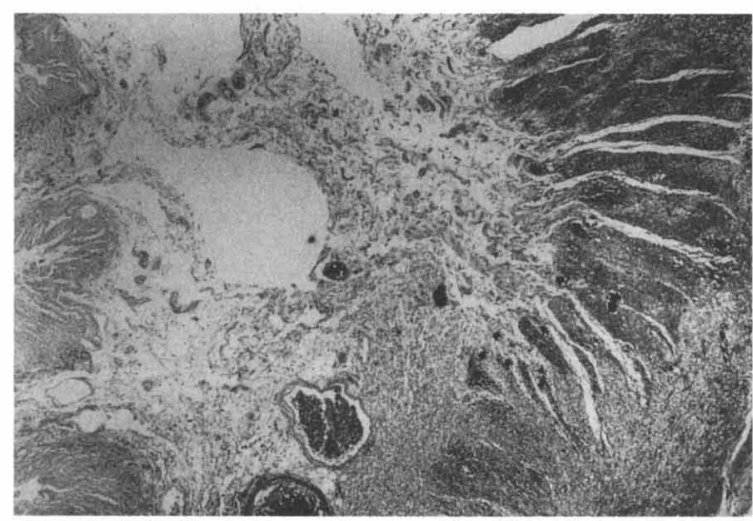

図 15 組織像. 症例

64 歳, 男性

病変の主体は乏血による大腸粘膜の凝固壊死で, 二次 的に墏膜側の炎症が生じたものと考えられる

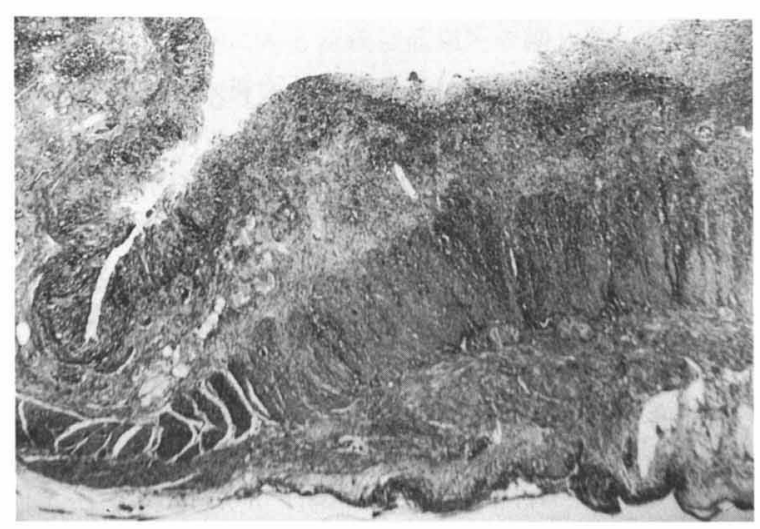

図 16 症例 36 歳, 男性

腸管全層の壊死と炎症性細胞の高度の浸潤を認める 
生存している.ただし, 1 例が術後 1 年 6 力月を経過し た時点で総除水量が $5,200 \mathrm{~m} l$ に及び終了直後から腹痛, 嘔気, 嘔吐が出現して再出術を行っている.

そのほか，1例に術直後に内シャントの閉塞と脳硬塞 （図 17）による言語障害が認められたが, 後者も漸次回 復した.

生存しえた症例はいずれも術後, 低血圧状態を持続し ていることに変わりがない.血液透析は継続しえており, 最大許容除水量を各症例ごとに定めてこれを越えた場合 は翌日, 残余の除水のため追加透析とすることを原則と している.

\section{考察}

私どもが経験した透析患者に対する外科手術のうち, 48 例の腹部手術を, 今回検討の対象にした. 術前, 十分 な透析がなされれば, 透析患者であっても major surgery と言われるものに予想以上に耐術しうることを 知った. 腹部手術症例の多くは, 術前・術後にわたって 十分な経口摂取が障害されるため中心静脈栄養を必要と した. しかし, 高張ブドウ糖液を主体とする高カロリー 輸液は症例によっては糖過剩投与による強い口渴, 意識 混濁などの障害や全身の異和感を招来するため, インス リンを併用しつつ経時的に投与カロリーを増加していく 等の処置は腎機能正常者の場合以上にこまかい配慮が必 要であった. また, 透析症例に対するアミノ酸製剤とし て AMI-U-II ${ }^{\circledR}$ の使用が一般的であるが，これを疑問 視する報告 ${ }^{1)}$ ありこの方面の研究が今後の課題の 1 つ であろう.

現に存在する感染や術後の感染を防止するために使用 する抗生剂に対してもその用量に十分な配慮が必要であ る. 肝障害, 搔痒症, 中毒疹などのほか意識障害の原因 となりうるからである. 幸いに, 透析による除去率の判 明した抗生剤が次第に数多くなって, 抗生剤の使用が単 に経験によらず理論にうらづけされて安全, 適正となっ てきている ${ }^{13,14)}$.

術後の合併症として心肺機能低下によると推測される 胸部 X線上, 肺うっ血, 心肥大を呈する急性心不全かそ の類似状態が多くみられ，もっとも注意を払うべきこと を痛感した。

これは必ずしも輸液, 輸血の過剩投与に起因するもの ではなく lean body mass の消耗が dry weight の実質的 な減少をきたした結果として溢水状態をもたらしている ものと考えられた. したがって術後の dry weight は種々 のデータを参考に頻回に設定し直していく配慮が必要で ある.

胃・十二指腸潰晹の出血例に対する胃切除は最も回数 の多い手術であったが, 過去 2 年間は皆無となっている.

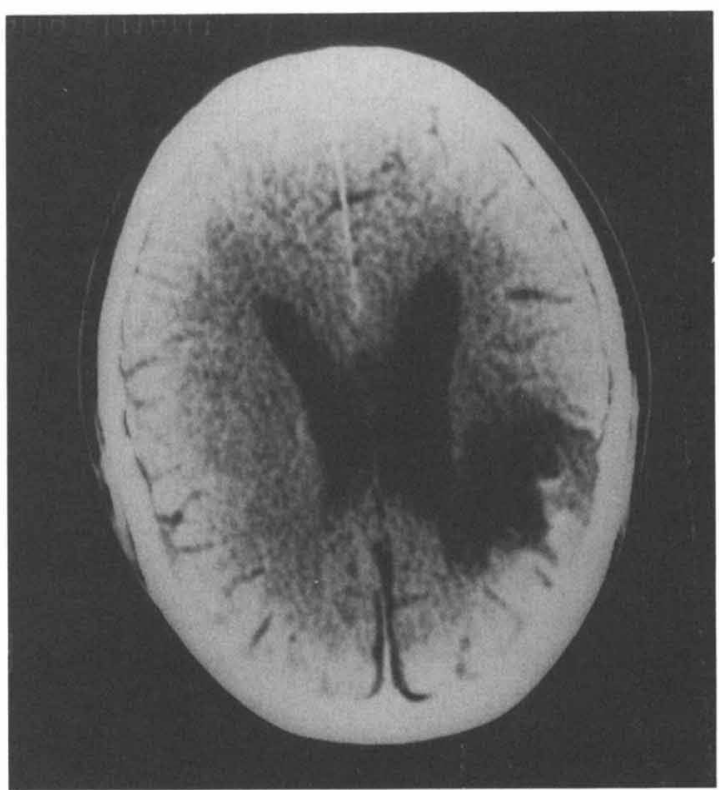

図 17 脳 CT 像. 症例 64 歳, 男性 (術後) 左前頭葉に大きな低吸収域を認める

これはシメチジンの投与 ${ }^{15)}$ や内視鏡的止血法の採用に よって減少したとの印象を持っている，消化性潰瘍は穿 孔や大出血などの合併症を併発しない限りシメチジンな ぞ $\mathrm{H}_{2}$ 受容体拮抗剤によって革命的とも言うべき治療効 果を挙げているが,一方では休薬による再発率も高い ${ }^{16)}$.

腎不全者に用いる場合には容易に血中濃度が上昇し意 識障害その他の副作用を呈することもあるが, 血液透析 による本剤の減少率は約 $70 \%$ でありこれらの点を考慮 して投与量を決定しなければならない ${ }^{17,18)}$. 私どもはシ メチジン $400 \mathrm{mg} /$ 日を長期に用いた症例があるが，特に 蓄積効果は認めてはいない.

いずれにせよ，消化性潰瘍のため手術を要する症例は 透析患者においても減少しているが，一方では患者の延 命とともに消化器系悪性腫瘍の症例は増加しており, し たがって今後は悪性腫瘍の手術が増加するものと予想さ れる ${ }^{1,19,20)}$.

次に虚血性腸管壊死であるが, これは虚血性大腸炎 (ischemic colitis) の 1 型と考えられるものである. 虚血 性大腸炎は，1) 血管閉塞，または血行不全の範囲，2） その持続期間, 3 ) 側副血行路の発達程度, 4) 二次的 細菌感染の程度, 範囲によって 3 つの異なる臨床像をと るものと考えられる.

すなわち，1）一過性虚血性大腸炎 (transient ischemic colitis), 2 ) 狭窄性虚血性大腸炎 (stricturing ischemic colitis), 3 ) 壊死性虚血性大腸炎 (gangrenous 


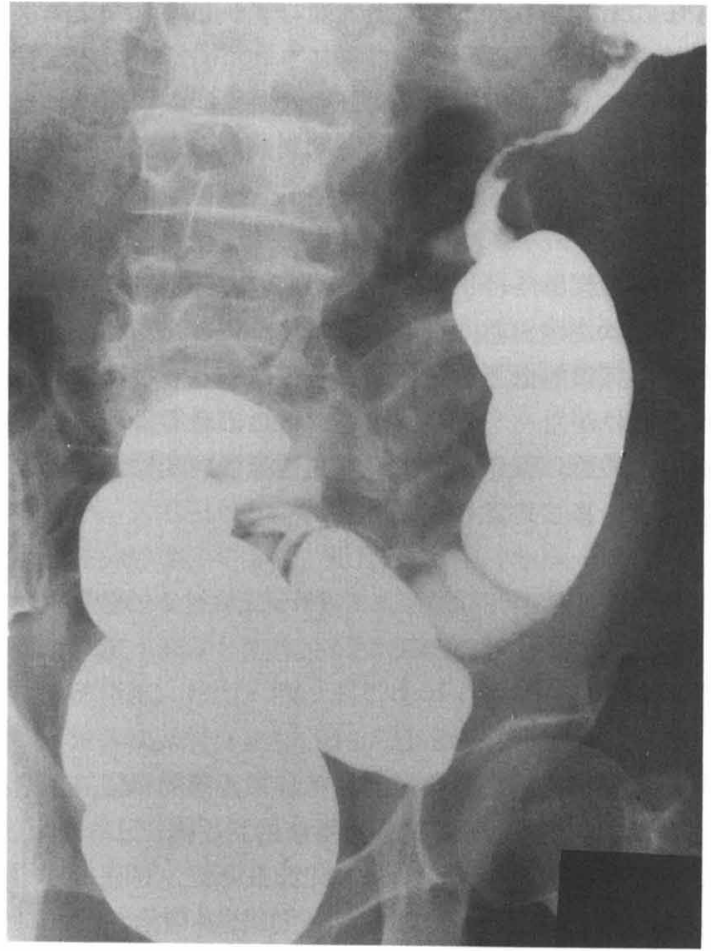

図 18 注腸造影像

下行結腸中部に著明な狭窄がみられる（非透析症例）

ischemic colitis) である ${ }^{21)}$. 幸いなことに，一般には病 変が進行して壊死にまでいたることは稀れである22).

図 18 は腎機能の正常な 57 歳男性にみられた狭窄性虚 血性大腸炎の注腸造影であり, この症例は下血と腹痛を 繰返し大腸癌の疑診であった ${ }^{23)}$. 組織学的には腸管壁の 変性が認められる（図 19，20）。

虚血性大腸炎は大腸のどの部分にも発生しうるが，一 般には左結腸曲から S 状結腸にかけてみられることが多 (24).

一方, 透析患者における自験例類似の症例を欧米文献 にみると, ischemic colitis ${ }^{25)}$, ischemic bowel disease ${ }^{26)}$, spontaneous perforation of the colon ${ }^{27,28)}$, non-specific ulcer of the colon ${ }^{29)}$ などとして報告されている. Huded ら ${ }^{29)}$ は慢性血液透析患者に発生した非特異性結腸潰瘍 (non-specific ulcer of the colon) を 12 例集計している が, 病変部位は盲腸 6 例, 盲腸および上行結腸 1 例, 盲 腸および下行結腸 1 例, 上行結腸（右結腸曲） 1 例, S 状結腸 1 例, 不明 2 例である.

透析期間は判明している 6 例では数力月から 9 年に及 ぶ. また 12 例中 9 例に顕性の下血が認められている. 全 12 例が腎移植術を受けてその術後 1 週間から 2 年末満

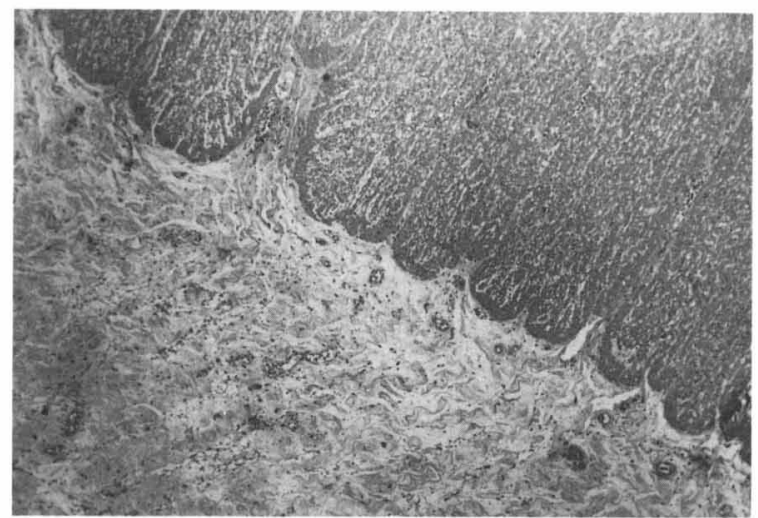

図 19 組織像

病巣部における粘膜下組織の浮腫と内輪筋の空胞性変性

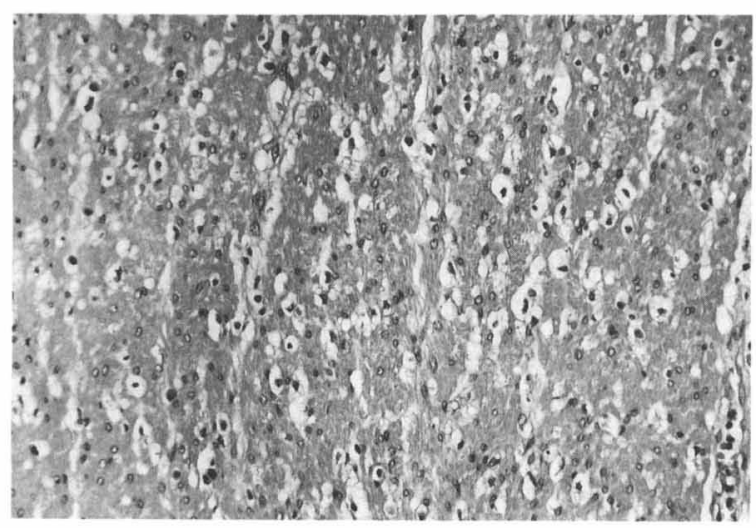

図 20 組織像

粘膜下組織の内輪筋に空胞性変性を認める（強拡

大). 炎症は目立たず循環不全を示唆する

の時期(すでに拒絶反応のため血液透析へ復州している) に本症を呈しているが，既往の手術との関連性は否定し ている. 引用した欧米の諸報告では発熱, 血性軟便, 腹 痛, 嘔吐などを初発症状としており, 自験例と類似して いるが，自験例にみる持続性低血圧や繰り返す腹痛に関 してや血液透析操作との関連性については明確な記述が ない.

しかし, ischemic colitis (Aubia) ${ }^{25)} ゃ$ spontaneous perforation of the colon (Lipscutz) ${ }^{28)}$ では低血圧によ る腸管の乏血は誘因として強調されており, その他, 腸 管蠕動運動の低下, 慢性便秘や動脈硬化が誘因として挙 げられている。

本邦でも本症の報告は最近, 増加している $3^{30 \sim 34)}$. 自験 例を加えてこれら 12 例の発生部位をみると, 回盲部 8 例, 上行結腸 1 例, 右結腸曲 2 例, 下行結腸 1 例である. 私どもと同様にいずれの報告者も低血圧, 大量除水を誘 因として重要視している. 
さて，自験例はいずれも病理組織学的に虚血性腸管壊 死の像を呈した。

腸管の壊死は，腸壁自体あるいは壁内血管の障害また はその支配血管の機能的, 器質的閉塞によって生ずる.

私どもの 5 症例は壊死腸管の支配血管の血流異常すな わち腸間膜血管閉塞症 (mesenteric vascular occlusion) と推定される. 本症は動脈閉塞, 静脈閉塞, 非閉塞性梗 塞 (non-occlusive mesenteric infarction) とに分類され $3^{35)}$.

自験例は持続性低血圧, 繰り返す透析後の腹痛という 臨床経過, 腸間膜動静脈系に明らかな器質的病変を認め ないという手術所見ならびに腸管全層に及ぶ壊死という 病理組織学的所見などから非閉塞性腸間膜梗塞症と推測 される。

非閉塞性腸間膜梗塞症の病因は不詳であるが，心拍出 量の持続的低下に関係しており, 例えば敗血症, 急性心 筋梗塞, 遷延性ショック状態などで起こる ${ }^{35)}$. そこで, 透 析患者に発生する本症の原因を探ると自験例では持続性 低血圧のため腸管は常に乏血に近い状態にあり，これが 透析による除水 (hypovolemia) で一層悪化したものと 考元られる. 持続性低血圧の透析患者は透析間体重増加 が比較的大きい傾向にあり, したがって除水が一層困難 となり血圧はさらに低下する，このため，腸管の乏血は 各透析ごとに繰り返し発生することになる。こうした病 態が動脈硬化や除水による血液濃縮さらに未知の尿毒症 状態によって種々に修飾され，ついに可逆性の変化へい たるものと推定される. 自験例ではいずれも肉眼的な穿 孔を認めなかったが, 壊死腸管からの腸内容の漏出は あったと考えられ，したがってすべての汎発性腹膜炎の 状態であった.

これらの症例で乏血性または虚血性変化が，心ではな く1例の脳梗塞を除いてもっぱら腸管に重大な結果をも たらした点については不明である。

診断は持続性低血圧または透析時高度の血圧降下，高 度動脈硬化, 器質的心疾患などの risk factors を有し, 再三腹部アンギーナ発作を起こす患者の臨床経過に注目 することから始まる，患者の状態が急激に進行，悪化す るため血管造影や経口および注腸バリウムを行いえず， 確定診断は困難である.バリウム検査は穿孔をきたすた め，本症を疑った場合にはむしろ行うべきではない.

結局, 臨床経過, 全身状態, 腹部理学所見, 腹部単純 $\mathrm{X}-\mathrm{P}$, 末梢血所見などの総合で時期を逸することなく手 術を決定することになる。本症発生の予防上の対策は, 低血圧が大きな誘因と考えられるため，まず低血圧症例 や透析中血圧降下の大きい症例に対する血液透析上の 種々な方法を試みて, 個々の症例に最適な透析法を確立
することにあるが，実際上大変むずかしい，大量除水を 避けるために患者個々の自覚にもとづく厳密な体重管理 も重要である．末梢血および血液凝固能の状態によって は ticlopiridine（血小板機能抑制剤）の定期的内服が有 効である。

\section{結論}

自験の腹部外科手術 48 例を分析し, 透析患者と言えど も十分 major surgery に耐術しうることを知った。しか し，心肺機能低下を主体とする致命的ともなりうる合併 症も避けがたく十分な術前・中・後の患者管理が必要で ある. 最近, 報告の相次ぐ虚血性腸管病変についても自 験 5 例をまじえて考察した。

本論文の要旨は第 30 回人工透析研究会総会 (昭和 60 年 7 月，東京）において発表した。

\section{文献}

1）寺岡 慧，太田和夫，高橋公太，東間 紘，阿岸鉄 三, 吉田喜美子：透析患者の外科手術, 日本臨床(新 訂維持透析)，522：612-622，1985.

2）今井久彌, 高橋幸雄, 鈴木正司, 酒井信治, 上村 旭, 田尻正記, 湯浅保子, 出口隆志, 中村享道, 平沢由 平：メシル酸ガベキサート使用による血液透析中の 局所抗凝固法の試み。現代医療, 14：973-978, 1982.

3) Lempert, K., Whittier, F. : Slow continuous ultrafiltration using a polyacrylonitrile membrane (Abstracts). Blood Purification, 2:10, 1984.

4) Kramer, P., Kaufhold, G., Grone, H. J., Wigger, W., Rieger, J., Matthaei, D., Stokke, T., Burchardi, H., Scheler, F. : Management of anuric intensive-care patients with arteriovenous hemofiltration. Int. J. Artif. Organs, $3: 225-230,1980$.

5) Freidin, J., Marshall, V.: Illustrated Guide to Surgical Practice, p 206-207, 1984, New York, 1984.

6）島津久明：消化性潰瘍一外科的手術適応・外科の立 場から. Medical Practice, 2 : 908-913, 1985.

7）荒川弘道，正宗 研：消化性潰場一外科的手術適 応・内科の立場から. Medical Practice, 2 ：904-907, 1985.

8）横田和彦, 大島行彦, 内田久則, 比企能樹, 大島正 己：透析患者の外科手術, 開腹手術症例の検討。透 析会誌，13：101-107，1980.

9) Maher, J. F. : Pharmacological aspects of renal failure and dialysis. Chapter 39, p 779, Replace- 
ment of Renal Function by Dialysis (2nd Ed.), Martinus Nijhoff Publishers, Boston, The Hague, Dordrecht, Lancaster, 1983.

10）大川昌雄, 小高通夫, 平沢博之, 小林弘忠, 添田耕 司, 林 春幸, 菅井桂雄, 佐藤 博, 嶋田俊恒, 入 江康文：透析と外科手術一perioperative management を中心に. 透析会誌, $13: 95-100,1980$.

11）岡本啓子, 竹内紀子, 西 秀樹：透析患者の消化管 手術における術前術後の栄養管理について. 透析会 誌, $14: 79-81,1981$.

12）大平整爾, 阿部憲司, 佐々木偉夫, 田口宏一, 佐野 秀一, 久木田和丘: 慢性血液透析患者にみられた虚 血性腸管壊死の 3 例. 腎と透析, $16: 605-610,1984$.

13）大平整爾：血液透析患者に対するセフメタゾンの投 与試験。基礎と臨床, $15: 6041-6049,1981$.

14）柴田昌雄, 杉山 敏：透析患者における薬剤の選択 と投与法。腎と透析, $19: 51-56,1985$.

15）細井正晴, 加藤信夫 : 慢性透析患者の消化器外科手 術, 第 30 回人工透析研究会総会, 東京, 1985 .

16）酒井秀明, 広瀬完夫, 木平 健: 消化性潰瘍·治療, 内科的治療 - 攻撃因子の抑制 $-\mathrm{H}_{2}$ 受容体拮抗剤. Medical Practice, 2 : 878-883, 1985.

17) Larsson, R., Bodemar, G., Norlawder, B. : Oral absorption of cimetidine and its clearance in patients with renal failure, Europ. J. Pharmacol., $15: 153-157,1979$.

18) Jones, R. H., Levin, M. R., Parsons, V : Therapeutic effects of cimetidine in patients undergoing haemodialysis. Brit. Med. J., 1 : 650-652, 1979.

19) Ota, K., Yamashita, N., Suzuki, T., Agishi, T. : Malignant tumors in dialysis patients. A Nation wide survey. Proc. EDTA, $18:$ 724-730, 1981.

20) Bush, A., Gabriel, R. : Cancer in uremic patients. Clinical Nephrology, $22: 77-81,1984$.

21) Marston, A., Pheils, M. T., Thomas, M. L. : Ischemic Colitis. Gut, 7 : 1-10, 1966.

22) Miller, W. T., Scott, J., Rosato, E. F. : Ischemic colitis with gangrene. Radiol., $94: 291-297,1970$.

23）大平整爾, 阿部憲司, 佐々木偉夫, 田口宏一: 狭窄
性虚血性大腸炎の 1 例. 北外誌, $29: 53-57,1984$.

24）三島好雄：虚血性大腸炎の臨床. 胃と腸, 14 : 607-614, 1979.

25) Aubia, J., Lloveras, J., Munne, A., Solsone, J., Orfila, M. A., Riambau, E., Serrano, S., Llorach, M. : Ischemic colitis in chronic uremia. Nephron, $29: 146-150,1981$.

26) Margolis, D. M., Etheredge, E. E., Garza-Garza, R., Hruska, K., Anderson, C. B. : Ischemic bowel disease following bilateral nephrectomy or renal transplant. Surgery, $82: 667-673,1977$.

27) Bartolomeo, R.S., Calabrese, P. R., Taubin, H. L. : Spontaneous perforation of the colon. A potential complication of chronic renal failure. Digestive Diseases, 22 : 656-657, 1977.

28) Lipschutz, D. E., Easterling, R. E. : Spontanetus perforation of the colon in chronic renal failure. Arch. Intern. Med., 132 : 758-759, 1973.

29) Huded, F. V., Posner, G. L., Tick, R. : Nonspecific ulcer of the colon in a chronic hemodialysis patient. Am. J. Gastroenterology, 77 : 913-916, 1982.

30）前田真一, 出口 隆, 蠏本雄右, 加藤英夫 : 長期血 液透析患者に発症した腸間膜血管閉塞症の 1 例. 腎 と透析, $11: 347-351,1981$.

31）井上喬之, 松下義樹, 聴涛貴一郎：慢性透析患者に みられた虚血性盲腸壊死の 2 例. 透析会誌, 17 : 225-226, 1984.

32）飯田宜志, 新保隆郎, 飛田美穂：血液透析患者にみ られた虚血性大腸炎の自験例。透析会誌，18：105, 1985.

33）佐藤直毅, 小暮洋暉, 田島芳雄, 小林直彦, 橋本玄 之, 八木 繁：血液透析患者における虚血性大腸炎 の検討. 第 30 回人工透析研究会総会, 東京, 1985 .

34）来山敏夫, 草場泰之, 進藤和彦, 斉藤 泰, 石川 啓, 三浦敏夫：下部消化管穿孔をおこした血液透析患者 の 3 症例, 第 30 回人工透析研究会総会, 東京, 1985 .

35）馬場正三：腸管の阻血性病変による急性腹症. 消化 器外科セミナー (9), p. 284, へるす出版, 東京, 1982. 